\title{
CZECH ECONOMIST KAREL ENGLIŠ \\ AND HIS RELATION TO THE AUSTRIAN \\ SCHOOL IN THE FIRST HALF \\ OF THE $20^{\text {TH }}$ CENTURY
}

\section{Ilona Bažantová*}

\begin{abstract}
This article analyses opinions and teleological approach of Czech economist Karel Engliš (18801961) and his relation to the Austrian Economics during the first three decades of the $20^{\text {th }}$ century. He grew out from the Austrian subjective psychological school although he later refused its methodological psychological subjectivism and value theory. Engliš formed an original teleological economic school upon Kant's noetics. This paper describes Engliš's relation to the Austrian school: the polemic approach of Karel Engliš to Austrian Economics, followed by Engliš's agreement with certain postulates of the Austrian School. Engliš supported the conclusions of the Austrian School regarding irreplaceability of economic individualism as the basis for a modern economic market system.
\end{abstract}

Keywords: Karel Engliš, Czech economic thought, the Austrian School, methodology, teleological approach, history of the Austrian School

JEL Classification: B19, B25, B31, B41

\section{Introduction}

The article focuses on the personality of Karel Engliš (1880-1961), who was and still is important for many reasons (Vencovský, 1997). One of them is the formulation of its original teleological theory. Karel Engliš's economic thought is derived from theories of founders of the Austrian School. Ludwig von Mises in his work The Historical Settings of the Austrian School of Economics states: “... among the students of Menger, Böhm-Bawerk, and Wieser there were also non-German Austrians. Two of them have distinguished themselves by eminent contributions, the Czechs Franz Cuhel and Karel Englis." (Mises, 2003, [1969], p. 19).

The aim of this paper is to introduce the personality of the outstanding Czechoslovak inter-war (between WWI and WWII) economist, philosopher and politician Karel Engliš in relation to the Austrian School; first, the polemic approach of Karel Engliš to Austrian Economics will be described, followed by Engliš's acceptance of, and agreement with, certain postulates of the Austrian School.

* Ilona Bažantová, Charles University in Prague, Faculty of Law, Prague, Czech Republic (bazantov@prf.cuni.cz).

Auhtor specializes in the history of Czech and Czechoslovak economic thought between the $19^{\text {th }}$ and the first half of the $20^{\text {th }}$ century. 


\section{The Austrian School and Karel Engliš}

The Austrian School started its development in the Austro-Hungarian Monarchy in the final third of the $19^{\text {th }}$ century; methodologically, it became distinct from the German Historic School which was dominant in the Central European region of that time. The founder of the liberal Austrian subjective and psychological School was Carl Menger (1840-1921); Eugen von Böhm-Bawerk (1851-1926) and Friedrich von Wieser (1851-1926) were other representatives of the School. They succeeded in turning Vienna into a new centre of economic sciences during the first two decades of the $20^{\text {th }}$ century. What is less known is the fact that in Bohemia, as part of the Austro-Hungarian Monarchy, Austrian economics was developed and promoted particularly at the German part of the Prague University. ${ }^{1}$ It should be noted that F. von Wieser delivered his lectures at the German part of the Prague University between 1884 and 1902, Emil Sax delivered his lectures between 1879 and 1893, and Robert Zuckerkandl delivered his lectures between 1894 and 1926.

Albín Bráf(1851-1912) taught at the Czech part of the University. He always paid high attention to methodological issues both in his publications and teaching at the University (Doležalová, 2013). Bráf explained the theory of national economy in accordance with the Austrian Psychological School (Bráf was influenced by the works of K. Menger); however, he expressed certain reservations regarding its approach as he took quite a critical view on the School's excessive emphasis upon psychological aspects. Bráf did not use the analysis of "robinsonades" (an example of the solitary figure) and, besides deduction, his methodology included inductive examination of relevant issues (Bažantová, 2013, pp. 80-82). Bráf fully accepted Böhm-Bawerk's criticism of Marxism built upon a conflict between Part I and Part III of Marx's Capital. Most of Bráf's students became significant inter-war Czechoslovak economists and politicians, including Karel Engliš.

The process of developing Austrian economics continued in Prague and Brno after constituting a new sovereign state in 1918 - Czechoslovakia (Bažantová, 2009, pp. 566-567). In 1918 Karel Engliš as a Deputy ${ }^{2}$ substantially contributed to the constituting of Masaryk University, and it's Law Faculty, in Brno. From the middle 1920s, Engliš had a substantial influence upon Czechoslovak fiscal and monetary policy; he was appointed the Minister of Finance six times: between September 1920 and March 1921 and between 1925 and 1931 (Doležalová, 2007, pp. 51-60). He acted as the Governor of the central bank (the National Czechoslovak Bank) between 1934 and 1939 (Bažantová, 2005, pp. 72-74). On $21^{\text {st }}$ April 1947 Engliš was elected president (rector) of Charles University in order to head, as a recognized European scholar, the University in 1948 - the year of its $600^{\text {th }}$ anniversary. However, after the Communist coup d'état in February 1948 Engliš was

$1 \quad$ Charles University in Prague (founded in 1348) was institutionally and linguistically divided in 1882: every department and institute at all four faculties was divided into two parts - one with Czech as the language of instruction and research, and the other with German as the language of instruction and research (with the exception of the University Library and Botanical Garden). The Czech-German linguistic division continued after the foundation of independent Czechoslovakia in 1918. The German Prague University (and German higher education in Czechoslovakia in general) ceased to exist in May 1945 whilst Czech universities were closed by the Nazis in 1939 and reopened after the liberation of the country in May 1945.

2 After constituting an independent Czechoslovakia, Engliš was elected a Deputy for the right-wing National Democratic Party and acted in the Czechoslovak Parliament until 1925. For the biography of Karel Engliš see Vencovský (1997, pp. 194-199). 
compelled to resign and forcibly moved from Prague. He lived in material poverty and was continually persecuted by the police; Engliš died in 1961.

Engliš's academic position as a full professor of national economy was continued until 1939 in Brno. Along with his colleagues (Václav Chytil, Miloš Horna, Vladimír Vybral, Alois Král, Jan Loevenstein) Engliš formed, and methodologically developed, a teleological school sometimes denoted as the Brno School of National Economy. ${ }^{3}$ Karel Engliš came from the Austrian School, but he went beyond its limits and began to build his theory upon a teleological method.

\section{Engliš's Teleological Approach}

Engliš derived his view on economic theories from Kantian noetic philosophy (Vaněk, 2000). The basis is an absolute clarification of concepts. "Every science must be notionally well-grounded. Should a science lack noetic foundations it is unclear and uncertain in its basic concepts. It connects diverse facts, uses incorrect methods and its outcomes are lacking certainty." (Engliš, 1930a, p. 14).

Whilst Kant recognizes two basic views on the existing world, namely "what should be" (a normative theory) and "what is" (a discipline of natural sciences), Engliš goes further in his thoughts and claims that "what should be" can be seen from a dual perspective. A person in the $20^{\text {th }}$ century is not only bound by his ability to observe objects and to analyse his mind, but he is also determined by legal regulations having a purely logical structure. ${ }^{4}$ Engliš divides sciences into groups and maintains three basic modes of perceiving and handling the reality: "The first mode stems from natural sciences with causality (cause - effect, consequence) upon which the knowledge of natural sciences is structured and organized; the second is teleological with finality (means, purpose) to arrange the content of thoughts considered as intended (by someone); the third mode is normative with a logical cause being the arranging principle." (Engliš, 1930a, p. 28).

Karel Engliš always insisted on precise and consistent use of terminology and definitions. He built his theory on logical foundations and observed the teleological conceptual order in all of his work. Engliš defines all concepts in a formal way and claims that all laws are of a formal nature. He rejects psychologism of the Austrian School (see below) particularly due to its causalistic perception, which Engliš considers impermissible in economics. Engliš designates his view on the economic science as teleological (teleos = purpose, aim). An individual observes the world according to what he wants or wishes, or does not want or wish. "When we regard phenomena, objects and actions as wanted (by someone) and when we wish to understand them, we ask: Why are they wanted? And the answer is: Because something else is wanted as purpose. Therefore we thus explain one wanted thing - the means, by another wanted thing - the purpose." (Engliš, 1946a, p. 11).

3 This School was destroyed by the Communist regime: most of its representatives were imprisoned and prosecuted without any chance of resuming their academic or research activities; their books were removed from libraries and their main centre - the Law Faculty of Brno University - was closed in 1950.

4 Professor František Weyr (1879-1951) from Masaryk University in Brno developed a normative (legal) theory the philosophical grounds of which were close to the approach of Engliš. In this context, for Engliš (as well as F. Weyr), the inspiration was normative legal theory of AustroAmerican professor of constitutional law and legal philosophy Hans Kelsen (1881-1973), whose Study of the Sociological and Legal Idea of Law Engliš translated in 1914. 
Unlike the Austrian School, Engliš does not consider wanting as a mental action. He calls the relationship between a purpose and the means as finality (1946a, p. 11).

Engliš claims that, for every purpose, we choose relevant means so that the purpose can be achieved. The final purpose in a chain of means and purposes will be never subordinate to any superior purpose. It is called the original purpose. Purposes achieved in order to achieve the final purpose are called derived. This all is a process wanted by someone. And this is the basis for Engliš's definition of economics: "Economic science deals with order within which individuals, as well as whole nations, strive to maintain and enhance their lives ... The science of the order where individuals and nations care about sustainable improvement of life." (Engliš, 1938a, p. 3). "Order in economy is purposive and results from purposive thinking." (Engliš, 1938a, p. 5).

The teleological theory of economics of Engliš based on the idea that the cognition and understanding of all the economic processes may be satisfactory from the scientific point of view only if it follows the purposiveness, the choice of aims and means and the rationality of making decisions and methods in the behaviour of all the economic subjects (the state, banks, households, enterprises, etc.). "He pointed out that the traditional tendencies in economic theory preferred the causal approach and they concentrated on the search and research of causal connections in economic reality and that they missed the knowledge of the sense of human doings. In the light of these ideas Engliš elaborated on the economic science as the science dealing with systems in which all the economic activity takes place; he approached the teleological solution of basic economic problems, i.e. the theory of value and price, the money, the wages, the credit, the currency rate, the tax system, etc. From the perspective of value and price he analysed principles of the balanced effort of market economy, the function of the state and, in particular, the aim, the methods and the limits of the state economic policy" (Vencovský, 1997, pp. 422-423).

\section{Engliš's Polemics with the Representatives of the Austrian School}

Engliš's criticism of the Austrian School was neither first nor sole. For example, critical approach of the German Historical School to the Austrian School was based upon adversary methodological positions - see the well-known "Methodenstreit" between Menger and Schmoller (Loužek, 1999). Engliš's polemics were interesting because they stem from similar methodological backgrounds and similar position was maintained by other Czech economists, such as a colleague of Englišs's Jan Loevenstein (1886-1932). Loevenstein argued with Böhm-Bawerk (1916/1917) pointing out at "the infertility of value theory of the Austrian School for the purpose of explaining exchange" (1919). Bráf's student František Čuhel (1862-1914) strongly supported the ordinal marginal utility theory and criticized Böhm-Bawerk's cardinalism (1907).

Engliš, for a major part of his scholarly life and career, was critically interested in the Austrian School (Vencovský, 1997, p. 230 ff.); he conducted many debates with supporters of the School. The most interesting debates are (in German and Czech languages) as follows:

a polemic with Emil Lederer (1882-1939) summarized in Englišss paper Der relative Nutzen und der Grenznutzen published in the Vienna Österreichischer Volkswirt (1928, pp. 1-51); 
- a polemic with Walter Weddigen (1895-1978) summarized in Englišs's article Erkenntnistheorie und Wirtschaftstheorie published in Jahrbücher für Nationalökonomie und Statistik (1930, pp. 641-657) and in the Czech language in Engliš (1929a, 1929b);

- a polemic with Oskar Engländer (1876-1937) summarized in Engliš’s article in the Czech language (1929c);

- a polemic with Aleksander D. Bilimovič (1876-1963) summarized in Engliš’s article Zum Problem der teleologischen Theorie der Wirtschaft published in the Austrian Zeitschrift für Nationalökonomie (1933, pp. 220-242); and in the Czech language in Engliš (1932a);

- a polemic with Hans W. Ritschl (1897-1993) in paper Teleologische Theorie der Staatswirtschaft published in FinanzArchiv (1932, pp. 64-91); in paper Zur teleologischen Theorie der Wirtschaft published in FinanzArchiv, (1932, pp. 569-588); and a polemic with Ritschl's Theorie der Staatswirtschaft und Besteuerung (1925) in the Czech language in Engliš (1932b, pp. 191-230).

The most extensive and well-grounded polemic was the following: in 1931, Ludwig von Mises $^{5}$ (1881-1973) and Arthur Spiethoff (1873-1957) issued a collective work Probleme der Wertlehre where the paper by Oskar Morgenstern (1902-1977) Die drei Grundtypen der Theorie des subjektiven Wertes was placed as the first (main) chapter. Morgenstern explained the latest version of the theory of the Austrian School relating to value (1931, pp. 1-42); this moved Engliš to an extensive critical analysis published as Erkenntnis-theoretische Kritik der österreichischen Wertlehre in Vienna in Jahrbücher für Nationalökonomie und Statistik (1933, No. 138, pp. 801-831). This criticism was also published in the Czech language under the title Noetická kritika rakouské školy o hodnotě [Noetic Criticism of the Value of the Austrian School] in the prestigious Czechoslovak economic journal Obzor národohospodárský [Horizon of National Economy] in 1933.

\subsection{Rejecting psychologism}

In several of his publications - Teleologie jako forma vědeckého poznání (1930a) [Teleology as a Form of Scientific Knowledge], Psychický a teleologický subjektivismus v cenové teorii (1930b) [Psychological and Teleological Subjectivism in the Price Theory], the foreword to the two-volume monograph Soustava národni hospodárství (1938a, 1938b) [The System of National Economy], and the article Noetická kritika rakouské školy o hodnotě (1933) [Noetic Criticism of the Value of the Austrian School] - Engliš blamed Oskar Morgenstern, and the whole at that time the Austrian School of Economics, for their psychologization. In particular, Engliš claimed that the findings of the Austrian School were deductive and speculative as they resulted from psychological findings, from assessing psycho-natural subjects, i.e. individuals; as a result, their findings were relevant only with respect to individual economy as they disregarded psychologically unidentifiable economies, such as state or public economies in general. The Austrian

$5 \quad$ Mises' articles were: Vom Weg der subjektivistischen Wertlehre [On the Development of the subjective Theory of Value], pp. 73-93; Die psychologischen Wurzeln des Widerstandes gegen die Nationalökonomische Theorie [The Psychological Basis of the Opposition to Economic Theory], pp. 275-295. 
theory did not consider a state as an economic entity. Unlike the Austrian School, Engliš included the state into the category of economic persons claiming that the state acted according to the same principles as individuals, or even more objectively, and that the state was more capable of creating a list of its needs in compliance with which the state was to make decisions. The state has its own objectives to be achieved and, at the same time, the state is one of the biggest players on individual markets (Engliš, 1929d).

Criticism was directed also against conceptual obscurity. Engliš claimed that the Austrian School (Oskar Morgenstern in particular) confused the notions of purpose, utility and usefulness. "The first mistake of the School is that it ascertains the difference between usefulness and utility. Morgenstern sees a quantitative difference between them as is expressed in the dichotomy of the abstract and the concrete." (Engliš, 1933, p. 361).... "In the situation of analysing utility and usefulness, all of a sudden needs are mentioned without any attempt to clarify the relationship among them. Yet need in the sense of the Austrian School is a psychological action.” (Engliš, 1933, pp. 361-362). Engliš explained that usefulness is a trait (property), utility is a change, i.e. implementation of a purpose. Such distinction between utility and usefulness is not quantitative, as Morgenstern thought, but qualitative - utility is not a special case of usefulness but it creates a logical condition for usefulness. ${ }^{6}$

Engliš argued that "the Austrian theory of value creates an individual economy lacking a purpose; for this School, needs do not arise from the purpose of economy, needs are psychological facts which are to be satisfied." (1933, p. 302). "A need expresses the relation of the purpose to the means, and not the relation of a person to the object. Variability of needs is based on the variability of the purpose. A cultural purpose gives rise to cultural needs, an economic purpose gives rise to economic needs.” (Engliš, 1933, p. 301).

To logically maintain his opposition, Engliš argued that the state cannot mentally yearn for something. In the case of both the state and an individual a need may be explained as the relation between the purpose and the means. "An observer sees the wanting of a means (bread) for a purpose (satisfying hunger) and attributes them to a person (an individual) in the same way as he attributes to the state that it needs arms for its defence." (Engliš, 1930a, p. 53). There is no need without a purpose; thus we should ask what the nature of a purpose is from which the needs are derived.

\subsection{Criticism of the theory of price and interest}

Engliš refused the Austrian interpretation of price; he argued that the theory considered an individual purchase in isolation placing in opposition the price paid and the thing purchased. Engliš disapproved of the Austrian construction of utility and value as he claimed the Austrian School did not take into account that for the buyer it is a choice among various relative utilities. Another mistake of the Austrian School in its interpretation of value, Engliš claimed, was that the value of money was considered as a value given without considering what was purchased for that money. Engliš argued (e.g. 1938a, p. 246; 1946a, pp. 77-80) that the marginal utility of money was determined by the utility of the least important thing (and need) which could be purchased for the (available) money and which was lost with the loss of the last monetary unit (available).

6 Engliš added quite a sarcastic footnote to his opinion: "It is typical that the School having built its theory upon the notions of use and usefulness does not even know what they mean.” (Engliš, 1933, p. 362). 
Engliš himself did not work with the theory of price but with the theory of price relations.

In addition, there was a dispute between Engliš and the Austrian School over the mode of calculation of the subjective value of a monetary unit, whether according to its marginal utility (according to the value of money felt in the case of its loss although there is no loss in the case of purchase as a monetary unit is used according to its highest relative utility), or according to the post-limit utility (if a person fails to pursue a certain purchase he may use the remaining money to satisfy his need he would have not satisfied had he completed the purchase since the latter need is first to be satisfied should the amount of money be augmented). Engliš considered the dispute to be unfruitful because neither the marginal nor post-limit utilities could be known in advance (Engliš, 1938a, pp. 259-261). According to F. Vencovský (1997, pp. 231-236), one of Engliš's students and later personal friends (Koderová, 2011), this particular dispute with the Austrian School was used by K. Engliš to substantiate his theory of price under which it is impossible to explain an individual purchase and individual price in isolation as prices of different things (goods) could be explained only as a compact set.

Similar argumentation and grounds were used by Engliš to refuse the Austrian theory of interest. Engliš claimed that the application of the Austrian theory of price to interest resulted in the fact that it was more a legal construct than an economic substance of the issue. "...Within the Austrian School the explanation of savings and loan dilutes in one, since interest explains only a loan and not savings which is possible and real even without interest... The Austrian School eventually cares only for creditors and explains why interest is required; however, its interpretation lacks any explanation why the debtor is willing to pay interest and, as a result, he is unable to set its rate on his principal." (Engliš, 1938a, pp. 369-371).

\subsection{The opportunity cost theory}

Another postulate which Engliš subjected to criticism was the opportunity cost theory of F. von Wieser (1893). Engliš (as well as the Austrian School) did not consider the spending of money as cost. Unlike the Austrian School, Engliš maintained that the cost is the labour one is willing to perform in order to obtain money as a means to attain a certain positive purpose. However, it should be expected that the purpose attained would lead to a larger positive than a negative utility (cost) of labour. The Austrian School considered the opportunity spent as cost. Spending money means losing the second best opportunity. Engliš considered cost to be a result of the past whilst the Austrian School considered it as contemporary. "At times attaining a useful end (acquisition or use of an asset) is inseparably connected with incurring a loss. In such a case one undertakes what is simultaneously useful and harmful only when the useful outcome outweighs the loss. ... Cost exists only in relation to possible return, and return only exists in relation to cost. These are correlative concepts. We must not forget that cost always means loss, i.e., diminution of the desired end, a real decrease, a worsening of the status quo. Cost is therefore a function of purpose, as is loss." (Engliš, 1946a, p. 19; 1992, pp. 17-18).

Engliš rejected the theory of the Austrian School regarding the decision-making with respect to the production of a certain thing. He argued it would be nonsensical to put a double cost against the utility of a thing produced: the cost of an alternative use of time and the cost of labour efforts. First the utility may not be put against an alternative use of time to produce another thing as there is no suitable technology, relevant qualification 
and so on. Should the utility of a thing produced be put against the utility of an alternative product then utilities of products at subsequent places, not only at the second place, could be so put as well. Engliš argued that if a person chooses just one thing from a number of things the chosen thing is usually the one most useful for the person; the second and subsequent things chosen are less useful. The person loses the utility of things not chosen. "Lost utility is not a cost.... It is selection, not a sacrifice of something."(Engliš 1929c, p. 796).

One more argument was raised by Engliš against the opportunity cost theory of the Austrian School. Namely that "we would have to provide, for every economy, a series of offers each of which would contain the offer of money and the amount of goods to be purchased; however, for every single case it would be necessary to construe how to form series of offers of other goods. Such procedure dilutes in infinity as the price of an individual thing cannot be construed." (Engliš, 1933, pp. 377-378).

\subsection{The crisis theory}

The founders of the Austrian School - Menger, Böhm-Bawerk and Wieser - were not deeply interested in the problem of the economic cycle and the crisis theory. The analysis of this problem is the task of Mises (first in 1912) and Hayek (1933); their theory claims that disequilibrium on market for loanable funds appears after monetary expansion.

On the other hand, Engliš showed a significant interest in the theory of crisis (1932c, 1934, 1938b). He got positively inspired by the liberal (Walras) view: The entire equilibrium order of economic organisations in the individualistic (capitalist) system rests upon the four markets (the market of goods and services, the capital market, the labour market and the foreign currency market) and their points of equilibrium. But the four markets are interdependent. As a result changes in one market - rising or falling prices - bring about changes in the other markets. For this reason there cannot be equilibrium in one market unless there is equilibrium in all the others. However, this also works up-side-down, i.e. towards restoration of the general equilibrium. Disequilibrium represents malfunctioning of the order, a crisis in the economic sense. Engliš (1938b, pp. 641-716) argued that the economy is in a cyclical decline which may have three main causes: 1. rationalisation (introduction of machinery and motors); 2. overproduction (speculative production leads to overstocking of inventories in warehouses and subsequently to declining production); 3. deflation (meaning lower prices, growth of real indebtedness and declining profitability, e.g. cause of the Great Depression).

\section{Accord with the Austrian School}

Engliš supported the conclusions of the Austrian School regarding irreplaceability of economic individualism as the basis for a modern economic system. In his concept of economic systems Engliš (1938a, 1946b) distinguished between two fundamental theoretical systems - individualism and solidarism; he provided three model examples of the economic functioning of a society within their framework. Individualism may assume an individualist-capitalist nature, or a nature of national cooperation (ethocratic). In solidarism only one model - solidaristic - is practicable. "Here is a fundamental difference between the individual as agent exercising care for himself and as an object of care exercised by someone else." (Engliš, 1946a, p. 45). Engliš considered the individualist economic system to be the only possible realistic system; in addition, he 
considered it to be the most effective and democratic. "If an individual is to exercise care for himself he must be free to acquire resources (i.e. labour as productive activity), to use his resources (i.e. to consume), and he must have control over his resources (control over things is ownership)." (1946a, p. 46). By his elaborating on the substance of economic systems Engliš provided scientific evidence on the non-functioning of the solidaristic model $^{7}$ as did the representatives of the Austrian School in their "economic calculations of socialism", or in resolving the economic calculation problem where they refused central planning.

Engliš was positively inspired by the Austrian theory of exchange in that there was no exchange if the outcome would be subjectively equivalent for both parties. "For exchange to take place it is necessary for the partners to possess goods which they want and to find the exchange mutually advantageous." (Engliš 1946a, p. 67). Menger as well as Engliš claimed that both parties should get more in exchange. Engliš noted that the stock of goods determines the marginal utility for either exchanging party, not the price. The price is determined by the utility of the last item of particular goods purchased within the economy. Market price-fixing, as conceived by E. von Böhm-Bawerk, is similar.

The approach of Engliš and the Austrian School to defining marginal utility is identical. They understand it as the significance of the last item of goods on the edge of economic availability; however, it should be noted that the Austrian School, much more than Engliš, emphasizes the psychological component of conduct of an individual. "Marginal utilities are proportional to prices, and the relationship between marginal utilities of different goods corresponds to the relationship of their prices. An individual will therefore continue to buy different goods to satisfy different wants until the marginal utilities derived from satisfying different wants by buying different goods are proportionate to their prices." (Engliš, 1946a, p. 38).

Similarly to Menger, Engliš distinguished exchange value and utility value although he called the latter as economic value. Common logic can be found between Menger's goods of the first order or higher orders and Engliš's primary and derived purposes: "The existence of our requirements for goods of higher orders is dependent upon the goods they serve to produce having expected economic character and hence expected value. In securing our requirements for the satisfaction of our needs, we do not need command of goods that are suitable for the production of goods of lower orders that have no expected value (since we have no requirements for them). We therefore have the principle that the value of goods of higher orders is dependent upon the expected value of the goods of lower orders they serve to produce. Hence goods of higher orders can attain value, or retain it once they have it, only if, or as long as, they serve to produce goods that we expect to have value for us." (Menger, 2007, [1871], p. 150). Goods of higher orders as well as derived purposes serve the production of goods of the first order and the attainment of the primary purpose. Both ideas include finality. However, Englišs's consideration subsists in that goods of higher orders serve as means for attaining derived purposes, and subsequently the primary purpose, and their value is the value of ordinary goods.

Both the Austrian School and Engliš refused inflation as an undesirable phenomenon and blamed the state for it. Unlike the Austrian School, Engliš did not see the origin

7 This was also a reason why the Communist regime forbade reading Engliš's books, which were removed from libraries. 
of inflation in increasing the amount of money in circulation; this is rather a consequence of inflation. Engliš claims that the main reason for generating inflation is artificially creating purchasing power through bank loans and state loans, artificially intervening at the price level (e.g. through tax collection, price regulation, cartel agreements), artificially depreciating the currency, etc. "When the government creates unwarranted command over resources, when it creates unwarranted income (without having itself contributed to the national product) ... In so doing the government raises artificially the level of nominal economic magnitude, it raises the price level and reduces the value of money, reduces the purchasing power of money." (Engliš 1946a, p. 130). Along with the Austrian School, Engliš saw the negative effect of inflation particularly in the uneven transfer of resources and, as a result, in shifts in purchasing power.

\subsection{Positive influence of Engliš}

Not only did Engliš find the Austrian School inspiring but also some representatives of the Austrian School found valuable for themselves contacts and discussions with Engliš. Besides polemics mentioned above (sub 3) published in journals and books, personal visits were paid by J. Schumpeter and E. von Böhm-Bawerk; L. von Mises visited Engliš several times as is mentioned in Engliš's family guestbook.

We may assume that, at the end of the 1930s and the beginning of the 1940s, Engliš was one of the sources of inspiration for Ludwig von Mises. Mises' praxeology as well as Engliš's teleology is based upon Kant's philosophy; they are built upon a presumption that an individual acts and his acting is intentional and purposive. Mises in his book Human Action (Mises, 1949) refers to Engliš when explaining intentional human acting: "There are for man only two principles available for a mental grasp of reality, namely, those of teleology and causality. What cannot be brought under either of these categories is absolutely hidden to the human mind. An event not open to an interpretation by one of these two principles is inconceivable and mysterious for a man. Change can be conceived as the outcome either of the operation of mechanistic causality or of purposive behaviour; for the human mind there is no third way available. [Cf. Karel Engliš, Begründung der Teleologie als Form des empirischen Erkennens (Brünn, 1930), pp. $15 \mathrm{ff.]} \mathrm{It} \mathrm{is} \mathrm{true,} \mathrm{as} \mathrm{has} \mathrm{already} \mathrm{been}$ mentioned, that teleology can be viewed as a variety of causality. But the establishment of this fact does not annul the essential differences between the two categories." (Mises, 1996, [1949], p. 25).

August von Hayek and Ludwig von Mises provided two different alternatives of methodology to the Austrian School. Mises developed praxeology, Hayek, having clarified the methodology of science (Hayek, 1942), developed an analysis of consequences of human behaviour and the theory of a spontaneous order. In his methodological paper, F. A. Hayek mentioned Engliš's teleology and refused it: "Some authors, particularly O. Spann, have used the term 'teleological' to justify the most abstruse metaphysical speculations. Others, like K. Engliš, have used it in an unobjectionable manner and sharply distinguished between 'teleological' and 'normative' sciences. (See particularly the illuminating discussions of the problem in K. Engliš, Teleologische Theorie der Wirtschaft, Brünn, 1930.) But the term remains nevertheless misleading. If a name is needed the term 'praxeological' sciences, deriving from A. Espinas, adopted by T. Kotarbinsky and E. Slutsky, and now clearly defined and extensively used by L. v. Mises (Nationalökonomie, Geneva, 1940) would appear to be the most appropriate." (Hayek, 1942, p. 278). 


\section{Conclusion}

Karel Engliš was an economist-theoretician who was widely recognized in Europe in the inter-war period. He grew out from the Austrian subjective psychological School although he later refused its methodological psychological subjectivism and value theory. The notional ambiguity of theoretical terms as pursued by the oldest Austrian economists and criticised by Engliš, is moved by rigorous implementation to the teleological order of thinking which presents the unique allowable way in economic science. Engliš supported the conclusions of the Austrian School regarding irreplaceability of economic individualism as the basis for a modern economic system.

Engliš formed an original teleological economic school upon Kant's noetic philosophy and critical idealism. Engliš's significance is in that he constituted a methodology, or noetics of the teleological mode of cognition. The object of teleological cognition is what is wanted (postulate), unlike an object of normative cognition, which is what should be, and causal cognition, whose object is what is. Engliš's economic opinions have certain nodal points with Austrian economics. Unfortunately, the Communist regime in Czechoslovakia after WWII barred Engliš, as well as other representatives of the so called teleological school, from their academic and scholarly activities and debates over the development of the Austrian economics after the war.

Although Engliš's polemics with the Austrian School was interesting in that the latter was built upon similar methodological grounds but Engliš strived to "improve" the interpretation of the price-fixing theory, not to deny it, today, their arguments regarding the theory of value may attract attention only as a story within the history of the Austrian School. Besides, Wieser's opportunity cost theory has been a firm part of mainstream economics; thus one may say that, historically, Engliš lost his argumentation battle. On the other hand, what may be perceived as rather inspiring is Engliš's argument of the state as an economic entity with its own objectives and interests directing the state in its decision making. ${ }^{8}$ This should be a lesson for contemporary economists and policy makers.

What may be considered as Engliš's greatest contribution to contemporary economics is his inchoate conception of economic systems: individualistic economic order and solidaristic order. Engliš proved at a theoretical level that the only effective economic system is the individualistic system. This theoretical opinion of Engliš was reflected in his economic and political practice: he refused to intervene in the market pricing mechanism, rejected a deficit state budget potentially leading to inflation, and attempted to maintain stable currency policy and sound public funds. This liberal legacy of Karel Engliš remains valuable even today.

\section{References}

Bažantová, I. (2005). Centrální bankovnictví v české historii po současnost: institucionální pohled. Central Banking in the Czech History to the Present Time: an Institutional View. Prague: Národohospodářský ústav Josefa Hlávky.

(2009). Národní hospodářství (National Economy), in Skřejpková, P., ed., Antologie československé právní vědy v letech 1918-1939 (An Anthology of Czechoslovak Legal Science in 1918-1939). Prague: Linde, pp. 563-569.

8 The similar view has appeared in the Theory of Public Choice in this time. 
(2013). Národohospodář Albín Bráf a jeho vztah k německé historické škole a k rakouské škole (Economist Albín Bráf and its Relationship to the German historical School and the Austrian School), in Doležalová, A., ed., Albín Bráf: Politik, národohospodár a jeho doba (Albín Bráf: Politician, Economist and his Time). Prague: Národohospodářský ústav Josefa Hlávky, pp. 77-82.

Čuhel, F. (1907). Zur Lehre von den Bedürfnissen: Theoretische Untersuchungen über das Grenzgebiet der Ökonomik und der Psychologie. Innsbruck: Wagner'schen Universitäts Buchhandung.

Doležalová, A. (2007). Rašín, Engliš a ti druzí (Rašín, Engliš and the Others). Prague: Oeconomica. (2013). Od Albína Bráfa k Josefu Mackovi - Příspěvek k výročí úmrtí dvou významných českých ekonomů (From Albín Bráf to Josef Macek - a Contribution to the Anniversary of the Death of Two Signifi cant Czech Economists). Politická ekonomie, 61(3), 428-438. DOI: 10.18267/j.polek.906.

Engliš, K. (1929a). Weddigenova sociologická teorie hospodářská (Weddigen's Sociological Theory of Economic). Obzor národohospodářský, 34, 353-377.

(1929b). Odpověd'Weddigenova (Weddigen's Answer). Obzor národohospodářský, $34,881-898$.

(1929c). Hospodářská theorie bez noetiky. Rozbor Engländrovy nauky o hodnotě a statcích (Economic Theory without Noetics. Analysis Engländer's science about the Value and Goods). Obzor národohospodářský, 34, 705-737 a 793-810.

(1929d). Theorie veřejných hospodářství (Theory of Public Economy). Obzor národohospodářský, 34, 81-97.

(1930a). Teleologie jako forma vědeckého poznání (Teleology as a Form of Scientific Knowledge) Prague: F. Topič.

(1930b). Psychický a teleologický subjektivismus v cenové teorii (Psychical and Teleological Subjectivism in the Price Theory). Obzor národohospodářský, 35, 81-106.

(1932a). Bilimovičovy námitky proti teleologické teorii národohospodářské (Bilimovič's Objections to the Teleological Theory of National Economy). Obzor národohospodářský, 37, 585-609.

(1932b). Theorie státního hospodářství (The Theory of State Economy). Prague: F. Topič.

(1932c). Deflační a racionalizační theorie krize (Deflationary and Rationalization Theory of Crisis). Obzor národohospodářský, 37, 1-24.

(1933). Noetická kritika Rakouské školy o hodnotě (Noetic Criticism of the Value of the Austrian School). Obzor národohospodářský, 38, 289-303 a 361-378.

(1934). Světová a naše hospodářská krize (The World and Our Economic Crisis). Prague: F. Borový.

(1938a, 1938b). Soustava národního hospodářství. Věda o pořádku, ve kterém jednotlivci a národové pečuji o udržení zlepšení života (The System of National Economy. The Science of the Order Where Individuals and Nations Care about Sustainable Improvement of Life). (a) 1; (b) 2. Prague: Melantrich.

(1946a). Národní hospodárství (National Economy). Prague: published by author. (1946b). Hospodářské soustavy (Economic Systems). Prague: Všehrd.

(1992). Economics: A Purpose Oriented Approach (Translated book 1946a). New York: Bouldner. 
Hayek, F. A. von (1933). Monetary Theory and the Trade Cycle. New York: Sentry Press.

Hayek, F. A. von (1942). Scientism and the Study of Society. Part I. Economica, New Series, 9(35), 267-291. DOI: 10.2307/2549540.

Koderová, J. (2011). František Vencovský: život a dílo (František Vencovský: Life and Work). Prague: Národohospodářský ústav Josefa Hlávky.

Loužek, M. (1999). Spor o metodu mezi Rakouskou ekonomickou školou a Německou historickou školou jako nejvýznamnější metodologický spor v dějinách ekonomie.

(Battle of Methods between the Austrian School of Economics and the German Historical School as the Most Important Methodological Dispute in History of Economics). Politická ekonomie, 47(4), 529-545. DOI: 10.18267/j.polek.59.

Loevenstein, J. (1916/1917). Kritika hlediska Böhm-Bawerkova na strast práce v subjektivním hodnocení. (The Criticism of Böhm-Bawerk Perspective on the Hardships of Subjective Evaluation). Sborník věd právních a státních, 17, 44-63.

(1919). Neplodnost hodnotné teorie rakouské školy pro vysvětlení směny (The Infertility of Value Theory of the Austrian School for the Purpose of Explaining Exchange). Sborník věd právních a státních, 19.

Menger, C. (2007). Principles of Economics (1871, Grundsätze der Volkswirtschaftslehre). Auburn: Ludwig von Mises Institute. Available at: www.mises.org.

Mises, L. von (1912). Theorie des Geldes und der Umlaufsmittel. München und Leipzig: Duncker \& Humblot, original reprint at www.mises.org. Wilkes.

[1949] (1996). Human Action. A Treatise in Economics. 4th Ed. San Francisco: Fox and

[1969] (2003). The Historical Setting of the Austrian School of Economics. Auburn: Ludwig von Mises Institute. Available at: www.mises.org.

Morgenstern, O. (1931). Die drei Grundtypen der Theorie des subjektiven Wertes, in Mises, L. von, Spiethoff, A., eds., Probleme der Wertlehre. Schriften des Vereins für Sozialpolitik. 183. München and Leipzig: Duncker \& Humblot, pp. 1-42.

Vaněk, J. (2000). Englišova teleologie jako filozofický základ ekonomického myšlení (Engliš's Teleology as philosophical Basis of Economic Thought). Politická ekonomie, 48(4), 469-481. DOI: 10.18267/j.polek.157.

Vencovský, F. (1997). Dějiny českého ekonomického myšlení do roku 1948 (A History of Czech Economic Thought Up to 1948). Brno: Nadace Universitas Masarykiana.

Wieser, F. von (1893). Natural Value. London: Macmillan and Co. 